\title{
METHODS TO EVALUATE FLOODS ON A BURNED WATERSHED
}

\author{
A.W. MILLER \& E.J. NELSON \\ Department of Civil \& Environmental Engineering, Brigham Young University, USA.
}

\begin{abstract}
This updated study focused on the methodologies, tools, and applications used to evaluate the hydrologic runoff potential of a burned watershed when few variables were actually measured. Forest fires often alter the balance between rainfall and the resulting runoff from natural watersheds. This may result in flooding from the burned watershed at locations downstream. Such was the case for the Mud Canyon watershed on New Mexico's Mescalero Apache Indian Reservation. In the spring, a fire burned approximately $42 \%$ of the watershed. Subsequent storms during the summer caused flows in Mud Canyon that led to flooding downstream at the town of Mescalero. The flooding was likely the result of inadequate remediation, neither human nor natural, during the months between the fire and the storms. While the summer storms that followed the spring fire had an updated magnitude to be expected every 10 years, the resulting updated flooding was more on the order of a 500-year event. A purpose of this study was to determine the amount of rainfall that produced the estimated flood flows. This result could then be used to determine the degree to which the burned portion of the watershed caused the flooding. The Burned Area Emergency Rehabilitation (BAER) Plan concluded that there was not a serious threat of flooding, based on the fact that the soils in the watershed were well-drained and not hydrophobic. The paper concludes that the loss of ground cover, particularly for relatively steep watersheds, should be seriously considered when evaluating the potential for flooding on a burned watershed. The methods used for this updated hydrologic analysis of Mud Canyon, as outlined in this paper, are applicable for future analyses of burned watersheds to determine the extent to which loss of ground cover contributes to increased flood flows.
\end{abstract}

Keywords: burned watershed, curve number, DEM, flooding, intensity-duration-frequency, return period, roughness.

\section{INTRODUCTION}

An April fire burned approximately $42 \%$ of the Mud Canyon Basin, a watershed on the Mescalero Apache Indian Reservation in the southeastern part of the U.S. state of New Mexico shown in Fig. 1. Subsequent storms during the summer caused flows in Mud Canyon that led to flooding downstream at the town of Mescalero. Some local residents claimed that the flood producing storms were typical for the area, and flooding was a result of inadequate remediation efforts (human or natural) during the months between the fire and the storms. Others felt that the flood was a result of extreme rainfall events.

If a rain gauge and flow-measuring device had been available in the Mud Canyon watershed, measured rainfall and flood flows could have been compared with typical events for that region to determine their severity. The purpose of this updated study was to determine the amount of rainfall that produced the estimated flood flows. This result could then be used to determine the severity of the rainfall events that caused flooding, and the degree to which the burned portions of the watershed caused the flooding.

The Burned Area Emergency Rehabilitation (BAER) Plan by the Department of the Interior [1] concluded that there was not a serious threat of flooding, based on the fact that the soils in the watershed were well-drained and not hydrophobic. However, significant flooding did occur. This paper focuses on the study and updated methodologies and applications used to evaluate the hydrologic runoff potential of the Mud Canyon burned watershed when few variables were actually known or measured. 


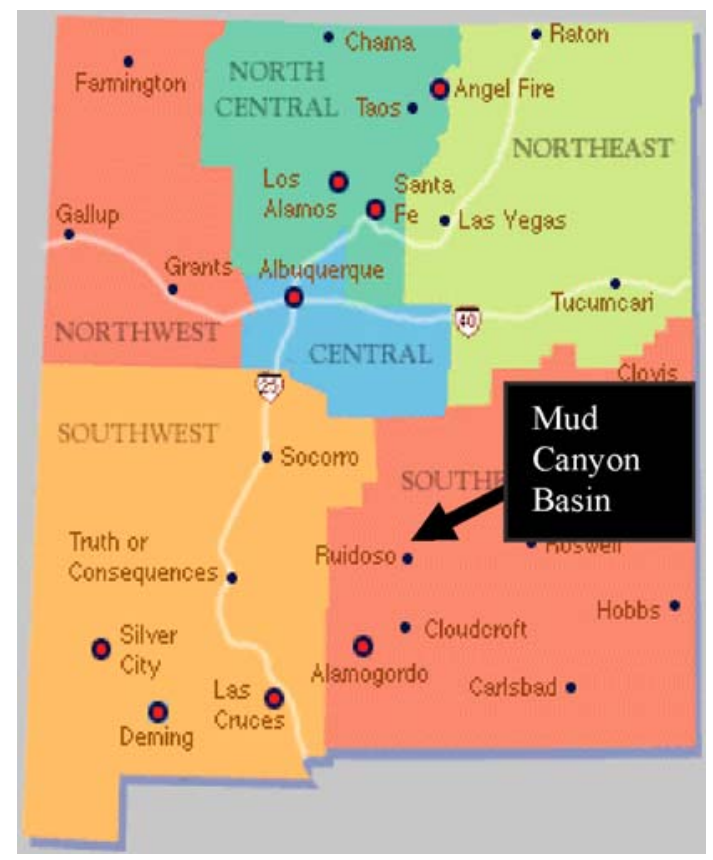

Figure 1: Location of Mud Canyon Basin.

\section{COMPUTER PROGRAMS USED IN ANALYSIS}

Because there were several unknowns (due to unmeasured parameters), different programs and models and data were used to simulate the basin hydrology and determine runoff response in a burned condition. The following sections describe the computer programs used in this study and how they simplified the process.

\subsection{National Streamflow Statistics (NSS) Program}

Flood-flow magnitudes and frequencies have been obtained by using statistical techniques and available flow gauging station data for a watershed. NSS is a program that uses regional regression equations developed from these gauging stations to estimate the magnitude and frequency of floods at ungauged sites. This is accomplished by analysis of watershed and climatic characteristics at gauged sites and transferring them to ungauged sites through characteristics, like watershed areas, elevations, slopes, lengths, precipitation, soil, and vegetation. These equations were recently revised, so our runoff analysis was also revised.

Updated regional regression equations used in NSS have been developed by the U.S. Geological Survey (USGS), in cooperation with the Federal Highway Administration (FHWA) and State Departments of Transportation (DOT). These equations have been derived for all the states in the United States and each state is further divided into hydrologically similar regions. Each region has different equations that require variables specific to the watershed being studied.

An example of a most recent NSS equation for the New Mexico southeast mountain region is:

$$
\mathrm{Q}_{5}=150,060 \mathrm{~A}^{0.662}(\mathrm{E} / 1000)^{-3.81}
$$


where $\mathrm{Q}_{5}$ is the five-year flow in cfs, $\mathrm{A}$ is the basin drainage area in square miles, and $\mathrm{E}$ is the mean basin elevation in feet according to Waltemeyer [2].

The equations are simple to use, but finding the correct parameters is sometimes difficult. Most variables may be estimated from the geometry and location of a specific watershed and reports such as the NOAA Atlas 2 maps from Miller et al. [3]. It should be noted here that the NSS equations have been derived by the USGS and others using English units (British Gravitational (BG) System) rather than metric (SI) units, and all our analyses have been in BG units.

\subsection{HEC-1}

As described in CEWRC-HEC [4], the HEC-1 model was developed by the Army Corps of Engineers Hydrologic Engineering Center to determine the runoff response of a watershed to a given storm. It has several methods for calculating runoff and is accepted as a standard model for rainfall runoff analysis.

The method used in this analysis is the Natural Resources Conservation Service (NRCS) runoff curve number $(\mathrm{CN})$ method from the Soil Conservation Service [5]. This NRCS method in HEC-1 uses hydrologic and geometric parameters to create a runoff hydrograph, with peak flow, runoff volume, and time to peak.

\subsection{Watershed Modeling System (WMS)}

WMS is a computer program developed at the Environmental Modeling Research Lab (EMRL) at Brigham Young University in cooperation with the U.S. Army Corps of Engineers Engineering Research and Development Center (USACE-ERDC). Nelson et al. [6] describe how WMS is used to characterize a watershed from digital terrain data, including automated basin delineation and parameter estimation.

The first step in the process is to acquire digital elevation data which are now widely available from local, state, and national resources. A digital elevation model (DEM) is a regular grid of elevations that defines the topography of a certain geographic region. DEMs are the critical underlying data set required to automate basin delineation and hydrologic modeling. Similar to a contour map, a DEM digitally represents the topography of an area by showing surface elevations at regular intervals. Each cell within the grid has an elevation with the horizontal coordinates defined at a single coordinate.

The spacing between elevations is referred to as resolution, with $1000,90,30$, and $10 \mathrm{~m}$ being the most common resolutions. The USGS is now deploying $90 \mathrm{~m} \mathrm{DEM}$ data for many locations around the world, which can be obtained from the USGS Website (http://seamless. usgs.gov). A region can be selected and downloaded free of charge.

DEM data can be used in GIS and hydrologic modeling programs like WMS to characterize watershed morphology and create hydrologic simulation models. Puecker and Douglas [7] and others developed algorithms to determine the flow direction from each of the DEM grid cells. From the flow direction vectors, flow accumulations can be computed and used to delineate watershed and sub-basin boundaries and calculate longest flow paths and other geometric parameters. Because vector GIS data structures are more easily managed, the delineated DEM basin boundaries are typically converted to polygons and basin streams converted to polylines.

A digital image of the background topographic map used to identify important land features along with the overlaid digital elevation model are shown in Fig. 2. 

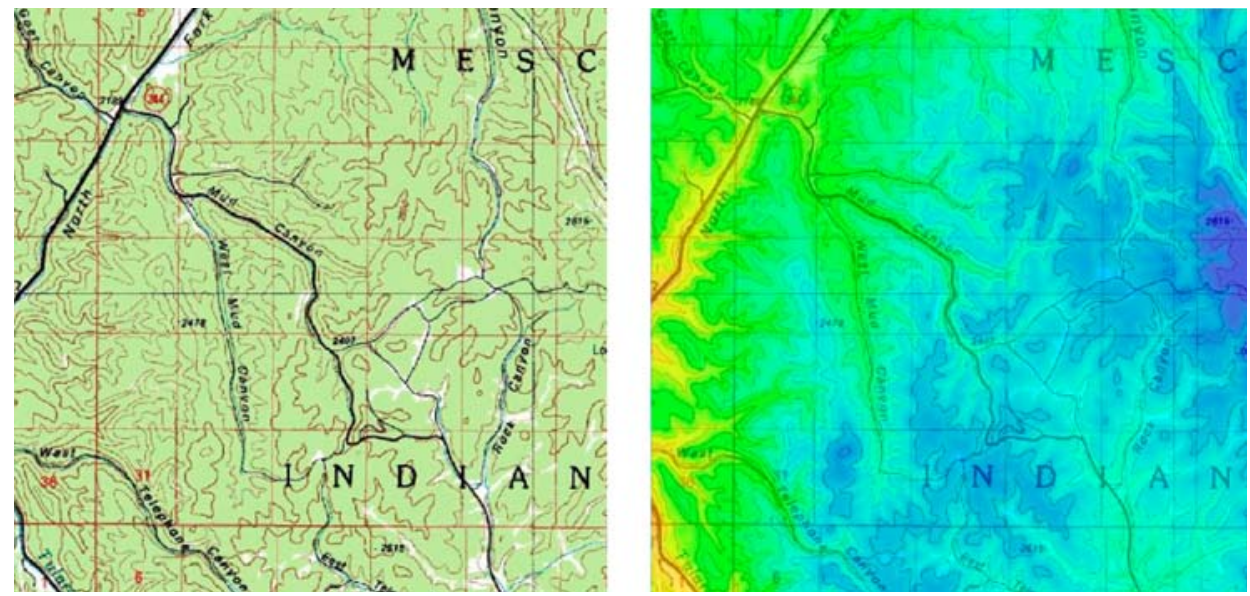

Figure 2: USGS digital topographic map and digital elevation model.
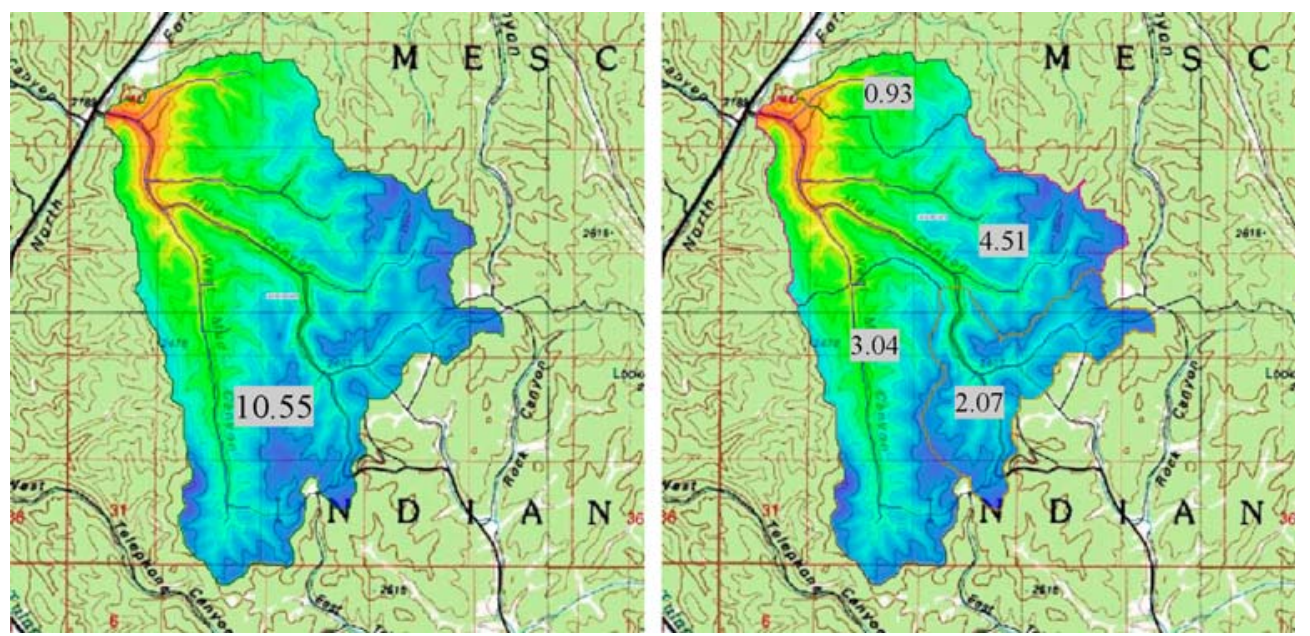

Figure 3: Delineated watershed and sub-basins.

With the digital elevation model, the TOPAZ D8 method described by Martz \& Garbrecht [8] for automated watershed delineation can be used to automatically delineate the watershed. The Mescalero Watershed was delineated in this fashion and the resulting area was determined to be 10.6 sq. mi. (27.4 sq. km) as shown in Fig. 3. The same methods can be used to further subdivide the watershed into multiple sub-basins. From the delineated watershed, computed basin data such as area, slope, and runoff distances can then be computed and used as input to a variety of supported models including NSS and HEC-1. This allows models to be easily developed and calibrated.

\section{METHODOLOGY OF ANALYSIS}

Because of the lack of measured precipitation and stream flow data in the Mud Canyon Basin before and after the fire, a unique modeling approach was needed. One of the major 
differences between this approach and traditional modeling studies was that runoff was used as the 'known', while precipitation was the 'unknown'.

The goal of the analysis was to predict the precipitation that caused the estimated flows near the mouth of Mud Canyon. After a literature review and numerous conversations with hydrologists, forest management personnel, eyewitnesses, and others with experience in floods resulting after forest fires, the following 10-step approach was developed and utilized.

1. Derive intensity-duration-frequency IDF curves for Mud Canyon Basin.

2. Create a terrain model of the basin using WMS for watershed delineation and computation of basin geometric parameters.

3. Compute basin lag times for both unburned and burned conditions.

4. Compute the flows for Mud Canyon Basin for unburned conditions using updated NSS equations.

5. Estimate the range of peak flows at the mouth of Mud Canyon based on a measured cross-section and high-water marks.

6. Use the flows derived from (4) to calibrate NRCS curve numbers for unburned conditions.

7. Determine curve numbers for the combined burned and wet condition.

8. Determine the appropriate precipitation distribution for HEC-1 analysis.

9. Use the estimated peak flow from (5), the curve numbers from (6) and (7), the lag times from (3), and the precipitation distribution from (8) in HEC-1 to back-calculate rainfall.

10. Compare the computed rainfall in (9) with the IDF curves generated in (1) to determine the return period of the storm that caused the flooding.

\subsection{IDF curves}

Two separate methods were used to obtain IDF curves for the basin. The first method used data collected from rain gauge stations in the area surrounding the basin. Precipitation data from the Department of Commerce [9] for southeastern New Mexico were obtained at the Cloudcroft, Ruidoso, and Mescalero stations, all of which are within 15 miles $(24 \mathrm{~km})$ of Mud Canyon and have similar climates.

The daily accumulations of more than one inch $(25.4 \mathrm{~mm})$ were found for these three stations and storm frequencies were determined from how often a given precipitation occurred. For example, there were 5 storms in 50 years that had a daily accumulation of 2.5 inches $(63.5 \mathrm{~mm})$, so it was assumed that a 2.5 inch $(63.5 \mathrm{~mm})$ storm occurs approximately every 10 years.

Rainfall data for these stations are only daily totals, not hourly. However, according to Leopold [10], storms in this region are generally short and intense during the summer season, so it was assumed that a single storm generally lasted less than six hours. The average intensities (inches $(\mathrm{mm}) / 6 \mathrm{hrs}$ ) and frequencies of these stations were used to create the 'stations' IDF curve shown in Fig. 4.

The second method used precipitation values from the NOAA Atlas 2 maps from [3]. These maps indicate how much precipitation is expected for a given frequency and storm duration for a given geographic region. The maps are derived for a 6-hour duration and frequencies of 2, 5, 10, 25, 50, and 100 years. The IDF curve derived from these values is also shown in Fig. 4, and compares well with the curve derived using historical data.

Both IDF curves in Fig. 4 are approximate, and are based on the best available data. The 'stations' IDF curve was developed from the historical data from the three nearby stations, 


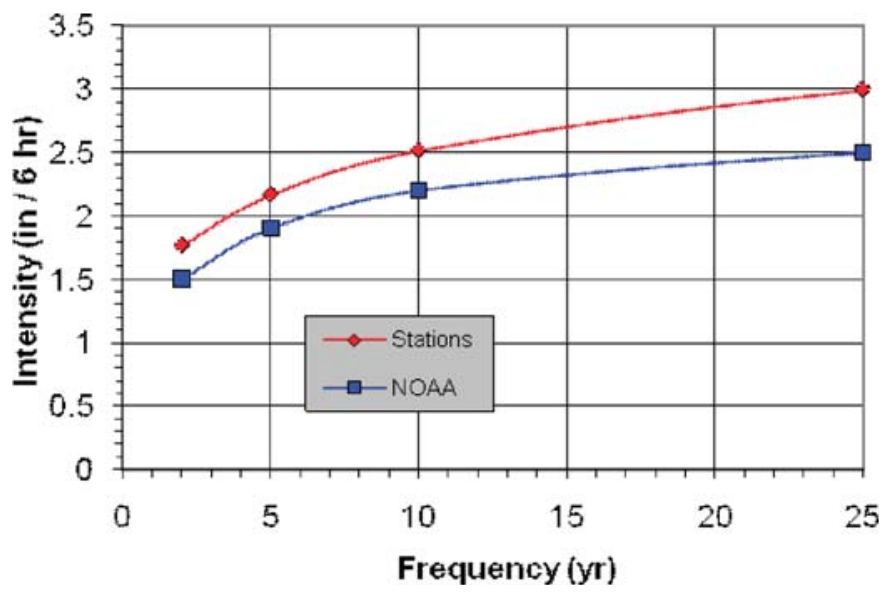

Figure 4: IDF curves for Mud Canyon.

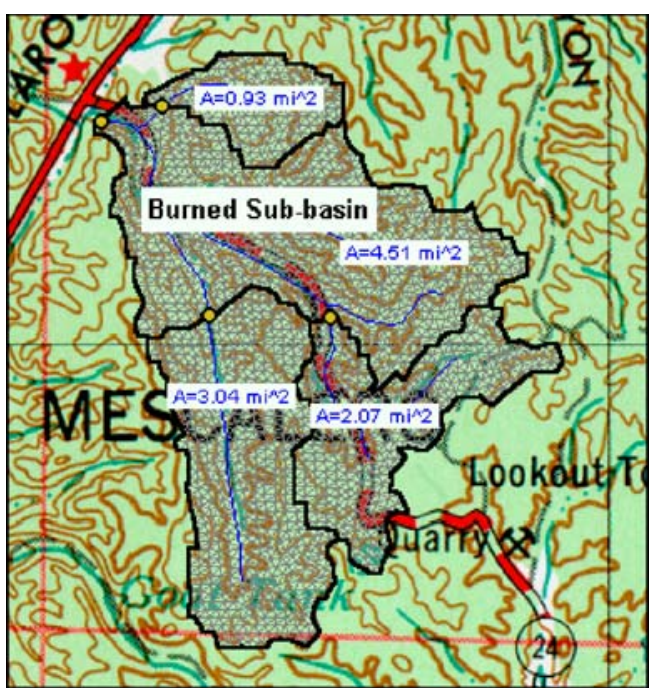

Figure 5: Sub-division of Mud Canyon into burned and unburned basins.

whereas the 'NOAA' IDF curve was developed from data in the NOAA Atlas 2 for New Mexico. We consider the 'stations' curve to be more representative in this case because of the use of local historical data. We also feel that using other models would not change the results significantly.

\subsection{Terrain model from WMS}

A DEM was obtained from the Bureau of Indian Affairs' geographic data center in Colorado. The portion of the DEM containing Mud Canyon Basin was extracted and these elevation data were used by WMS to delineate sub-basin boundaries shown in Fig. 5. Once the watershed boundary was delineated, geometric parameters for Mud Canyon Basin were computed. 
Mud Canyon Basin was further subdivided (Fig. 5) so that different parameters could be assigned to the burned and unburned areas. The natural sub-basin drainage boundaries were closely aligned with the burned regions. The BAER team reported [1] that the burned region covered approximately $42 \%$ of the basin, whereas the burned sub-basin in Fig. 5 covers $45 \%$ of the watershed.

\subsection{Lag time}

Conceptually, watershed lag time $\mathrm{T}_{\mathrm{LAG}}$ is the time from when the rainfall on the basin is most intense to when the discharge at the basin outlet is highest. Lag time is important because it determines the timing characteristics of runoff hydrographs in computer modeling programs such as HEC-1.

Several equations based on watershed shape, slope, vegetation, soil, and channel roughness have been developed to calculate the lag time. One such equation that is appropriate for the Mud Canyon Basin is the Riverside County mountainous equation from the Riverside County Flood Control and Water Conservancy District [11]:

$$
\mathrm{T}_{\mathrm{LAG}}=0.81\left[\left(\mathrm{~L} \mathrm{~L}_{\mathrm{ca}}\right) / \mathrm{S}^{0.5}\right]^{0.38}
$$

where $T_{L A G}$ is the lag time in hours, $L$ is the watershed length in miles, $\mathrm{L}_{\mathrm{ca}}$ is the length from the outlet to the watershed centroid in miles, and $\mathrm{S}$ is the weighted-average basin slope in feet/mile.

Again, it should be noted here that the lag time equations have been derived using BG units rather than SI units, and all our analyses have been in BG units. Since all of these variables are derived from basin geometry, WMS computes them as part of the automated basin delineation process. Using this equation, the lag times for each of the sub-basins were determined and are shown in Table 1. The lag time was determined to be 0.96 hours for the entire Mud Canyon Basin, and 0.77 hours for the burned sub-basin in an unburned condition.

The values above do not account for how the change in land cover and soil properties as a result of the fire affect the lag time. The burned watershed lag time is reduced because of the reduced ground cover and because the infiltration rates after the fire are lower according to Zwolinski [12]. Eyewitness accounts confirmed that the peak flows were coming out of Mud Canyon at about 30-40 minutes after the heaviest portion of the rainfall began.

On the basis of this information, the lag time in the burned sub-basin was reduced from 0.77 hours to 0.6 hours, a reduction of $\sim 25 \%$. Perhaps a less conservative adjustment would have been warranted, but due to many uncertainties, we felt this was the most appropriate. Furthermore, the overall analysis was not very sensitive to changes in lag time.

Table 1: Sub-basin lag times.

\begin{tabular}{lccccc}
\hline Sub-basin & $\begin{array}{c}\text { Area } \\
\text { (sq. miles) }\end{array}$ & $\begin{array}{c}\text { Length } \\
\text { (miles) }\end{array}$ & $\begin{array}{c}\text { Length to } \\
\text { centroid } \\
\text { (miles) }\end{array}$ & $\begin{array}{c}\text { Slope } \\
\text { (feet/mile) }\end{array}$ & $\begin{array}{c}\text { Lag time } \\
\text { (hours) }\end{array}$ \\
\hline North & 0.93 & 2.01 & 0.79 & 388.5 & 0.31 \\
Middle/burned & 4.51 & 5.17 & 2.43 & 224.7 & 0.77 \\
Southwest & 3.04 & 3.37 & 1.43 & 224.0 & 0.53 \\
Southeast & 2.07 & 3.25 & 1.34 & 174.0 & 0.53 \\
Total basin & 10.55 & 6.38 & 3.19 & 171.0 & 0.96 \\
\hline
\end{tabular}


Table 2: Results of NSS program.

\begin{tabular}{lc}
\hline $\begin{array}{l}\text { Frequency }(\mathrm{F}) \\
\text { year }\end{array}$ & $\begin{array}{c}\text { Flood flow }(\mathrm{Q}) \\
\mathrm{cfs}(\mathrm{cms})\end{array}$ \\
\hline 2 & $128(3.6)$ \\
5 & $266(7.5)$ \\
10 & $391(11.1)$ \\
25 & $584(16.5)$ \\
50 & $759(21.5)$ \\
100 & $957(27.1)$ \\
500 & $1554(44.0)$ \\
\hline
\end{tabular}

\subsection{Computed peak flows using NSS}

The required watershed parameters necessary to compute peak flows in this region using NSS are the basin area and the mean basin elevation. Area (10.6 square miles (27.4 square $\mathrm{km})$ ) and mean elevation (7955 feet $(2425 \mathrm{~m})$ ) were computed in WMS from the digital terrain model of Mud Canyon. Table 2 summarizes the peak flows determined for Mud Canyon Basin using the New Mexico southeast mountain region equations from the NSS program.

The statistical analysis used to generate the flood flows in NSS also produces standard errors. For the New Mexico southeast mountain equations they range from $35 \%$ to $50 \%$, which reflect similar uncertainties in estimated flows as developed in the next section. For the purposes of this study, we determined to use the most probable values as summarized in Table 2.

\subsection{Estimation of observed flows}

The flows that resulted in flooding during the summer of 1996 were large, but no measurements were actually taken in Mud Canyon during the floods. Estimates ranged from $1500 \mathrm{cfs}$ (43 cms) to $4000 \mathrm{cfs}(113 \mathrm{cms})$. Residual high water marks were used to establish a water surface elevation, and using Manning's equation for open channel flow, a range of peak discharges was calculated.

The cross-section at the mouth of Mud Canyon used to calculate conveyance parameters in Manning's equation was surveyed and is shown in Fig. 6. The cross-sectional area was $490 \mathrm{ft}^{2}\left(45.5 \mathrm{~m}^{2}\right)$ and the wetted perimeter was $160 \mathrm{ft}(48.4 \mathrm{~m})$. The channel and floodplain upstream slope was surveyed and found to be about $2.5 \%$. The range of flood flows was calculated based on a range of Manning's roughness coefficients from Maidment [13] for floodplains with flow depths into the tree branches of 0.09 to 0.15 . The flow at $n=0.09$ was $2700 \mathrm{cfs}(76.5 \mathrm{cms})$ and flow at $\mathrm{n}=0.15$ was $1620 \mathrm{cfs}(45.9 \mathrm{cms})$.

By comparing these flows with the pre-burn NSS values given in Table 2, it was concluded that the flood at the mouth of Mud Canyon was more than a 500-year return period flood. The question then was whether the precipitation that caused this flooding was also a 500-year event or did the burned condition of the watershed result in extreme flows from a relatively small rainfall event. 


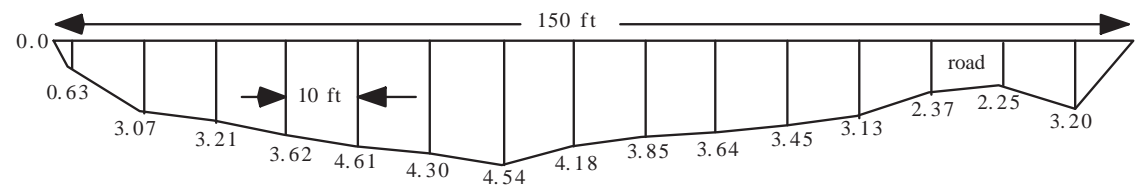

Figure 6. Stream channel cross-section near the mouth of Mud Canyon (feet).

Table 3: Calibration summary.

\begin{tabular}{lcccc}
\hline Freq.Yr & $\begin{array}{c}\text { Precip. (NOAA) } \\
\text { in(mm)/6hr }\end{array}$ & $\begin{array}{c}\text { Flows (NSS) } \\
\text { cfs (cms) }\end{array}$ & $\begin{array}{c}\text { Curve } \\
\text { numbers }\end{array}$ & $\begin{array}{c}\text { Flows (HEC-1) } \\
\text { cfs (cms) }\end{array}$ \\
\hline 2 & $1.5(38.1)$ & $128(3.6)$ & 66 & $136(3.8)$ \\
5 & $1.9(48.3)$ & $266(7.5)$ & 62 & $242(6.9)$ \\
10 & $2.2(55.9)$ & $391(11.1)$ & 60 & $373(10.6)$ \\
25 & $2.5(63.5)$ & $584(16.5)$ & 59 & $591(16.7)$ \\
50 & $2.8(71.1)$ & $759(21.5)$ & 57 & $736(20.9)$ \\
100 & $3.0(76.2)$ & $957(27.1)$ & 57 & $976(27.6)$ \\
\hline
\end{tabular}

\subsection{Calibrated curve number for unburned conditions}

The NRCS method from [5] for determining rainfall runoff uses the curve number (CN), which is a function of the land use and soil characteristics of the watershed. These include the hydrologic soil group, vegetation cover, treatment (management), hydrologic condition, and antecedent runoff condition.

A CN for Mud Canyon Basin in its unburned conditions was calibrated using the HEC-1 program in an iterative approach. By using the peak flows from the updated equations in the NSS program for unburned conditions, the precipitation values from NOAA Atlas 2 maps, and the basin lag time for unburned conditions, the $\mathrm{CN}$ was changed until computed flows matched the NSS values given in Table 2.

Table 3 summarizes the calibration procedure. Based on these results, an average $\mathrm{CN}$ of 58 was selected for unburned conditions. This value also compared well with the curve numbers for similar watersheds found in [11].

\subsection{Curve number for burned conditions}

To use the NRCS method in HEC-1, a CN for the burned area was also needed. A CN value of 77 was determined to be appropriate for a burned forest condition by [13]. Dan Murray of the NRCS office in Albuquerque said that a poor Ponderosa Pine forest with less than $30 \%$ ground cover would have a $\mathrm{CN}$ of $\sim 75$ (personal communication).

After a moderate fire, like in Mud Canyon, ground cover would be less than $30 \%$, and a CN of 77 is appropriate. The $\mathrm{CN}$ was also adjusted for the wet condition of the soil, since the flooding was preceded by more than 2 inches $(50 \mathrm{~mm})$ of rain over the previous five days. A normal condition $\mathrm{CN}$ of 77 is increased to 90 with this wet condition according to Wanielista et al. [14]. Therefore, a CN of 90 was used for a burned, wet forest. 


\subsection{Precipitation distribution}

A typical HEC-1 simulation requires precipitation as an input parameter, and peak flow is computed as the result. Because our unknown was precipitation, an iterative approach was used of running HEC-1 with different precipitation values to find peak flows. A mass distribution needed to be defined to show how this rainfall would be distributed over time.

Since the rainfall events in this area are typically short duration and eyewitnesses said that most of the rainfall generally occurred in less than one hour, a mass precipitation curve that distributed $90 \%$ of the rainfall amount during the third hour was used, as suggested by Leopold [10]. Further, since precipitation amounts were compared to those of the six-hour storm duration in the NOAA Atlas 2 maps, a total duration of six hours was used.

\subsection{Back-calculation of rainfall}

The previous sections described how parameters for the NRCS runoff method in HEC-1 were determined. With all the basin parameters established for both the burned and unburned subbasins, rainfall depth was back-calculated by changing the amount of rainfall until the peak flows at the mouth of Mud Canyon matched the range of estimated flows from the cross-section and high water marks (Fig. 4) of $1620 \mathrm{cfs}(45.9 \mathrm{cms})$ to $2700 \mathrm{cfs}(76.5 \mathrm{cms})$, which were based on the range of roughness values. The results of this iteration are shown in Table 3.

\subsection{Comparison of calculated rainfall to IDF curves}

The results of this analysis showed that the total rainfall required to produce a peak flow of $1620 \mathrm{cfs}(45.9 \mathrm{cms})$ was about 1.6 inches $(40 \mathrm{~mm})$ and for $2700 \mathrm{cfs}(76.5 \mathrm{cms})$ was about 2.1 inches $(53 \mathrm{~mm})$. On both IDF curves (shown on Fig. 4), 1.6 inches and 2.1 inches of rain correspond to about a $10-y r$ return period, or less.

Table 4 shows the peak flows produced by different precipitation values in the HEC-1 model. The hydrograph in Fig. 7 shows that of the $2683 \mathrm{cfs}(76 \mathrm{cms})$ (Table 4) produced by the 2.1 inches $(53.3 \mathrm{~mm})$ of rain, about $2500 \mathrm{cfs}(71 \mathrm{cms})$ was contributed by the burned

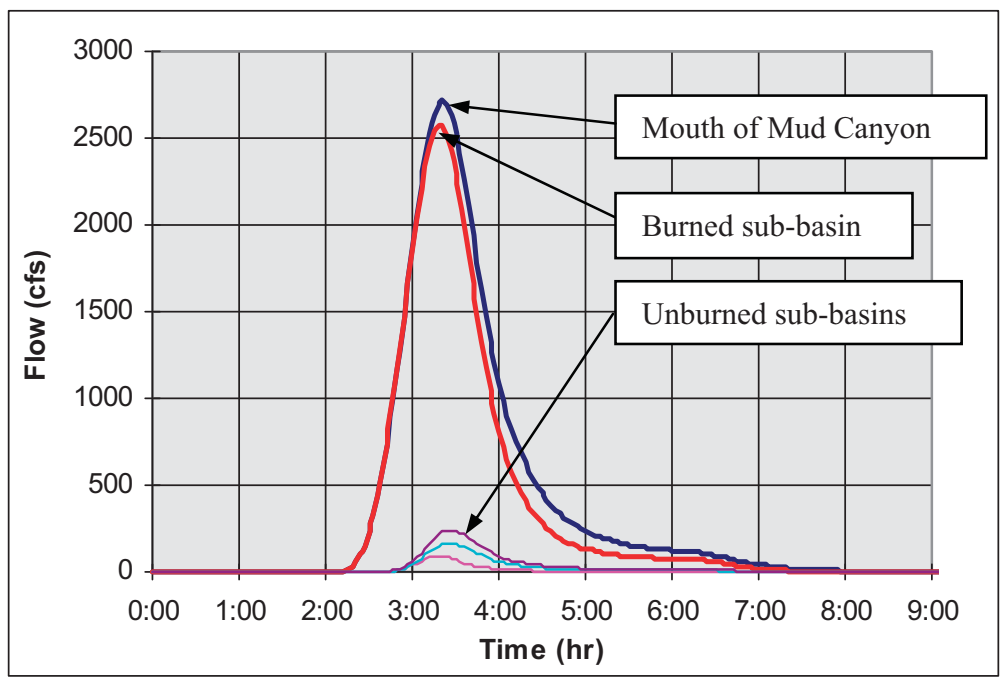

Figure 7: Hydrographs of entire Mud Canyon and sub-basins. 
Table 4: Results from HEC-1 iterations of precipitation values.

\begin{tabular}{lc}
\hline Precipitation in $(\mathrm{mm})$ & Peak flow cfs $(\mathrm{cms})$ \\
\hline $1.5(38.1)$ & $1543(43.7)$ \\
$1.6(40.6)$ & $1704(48.3)$ \\
$1.7(43.2)$ & $1877(53.2)$ \\
$1.8(45.7)$ & $2063(58.4)$ \\
$1.9(48.3)$ & $2260(64.0)$ \\
$2.0(50.8)$ & $2467(69.9)$ \\
$2.1(53.3)$ & $2683(76.0)$ \\
$2.2(55.9)$ & $2908(82.4)$ \\
\hline
\end{tabular}

sub-basin alone. In other words, less than $50 \%$ of the basin produced about $95 \%$ of the total peak flow. This was verified by Curtis Williams, Tribal Environmental Specialist, who said that he drove up Mud Canyon during one of the storms and noted that little, if any, flow was being contributed by the unburned portions of the basin (personal communication).

\section{COMPARISON WITH OTHER STUDIES}

The analysis presented above was unique in that both the flood flow and precipitation had to be determined for an ungauged location for both unburned and burned conditions. Our literature review found no studies that used this same type of analysis. However, some studies on runoff from burned watersheds were found and are useful in determining the relative accuracy of our results.

Campbell et al. [15] performed a study in Arizona that analyzed the effects of a fire on a Ponderosa Pine forest in an ecosystem similar to Mud Canyon. Runoff in the burned areas of the pine forest increased by more than eight times compared with the pre-burned runoff.

In the Snowy Mountain region of southeastern New South Wales, Australia, Brown [16] conducted a study on a watershed that experienced a severe burn. Although no values were given for the runoff increase compared to the unburned conditions, the final results state that the largest flood in the 19-year history occurred 10 months after the fire when the rainfall had a 'relatively very low intensity'.

Lavabre et al. [17] conducted a study in France on how a fire affected the runoff in a basin with marginal human influence near the Mediterranean Sea that had both precipitation and flow-gauging stations. A storm with a return period of less than one year produced a flood with a return period of more than ten years after the watershed had been burned.

Chow [18] described a study done in southern California that shows how fires affected the peak discharges from various watersheds. The results show that the peak discharge in a watershed increases dramatically after a fire, especially for smaller storms.

\section{CONCLUSIONS}

The following points summarize the findings of this study:

- The range of estimated flows at the mouth of Mud Canyon was from $1620 \mathrm{cfs}(45.9 \mathrm{cms})$ to $2700 \mathrm{cfs}(76.5 \mathrm{cms})$.

- The return period for a flood of either 1620 or $2700 \mathrm{cfs}$ in this region is more than 500 years. 
- The best estimate of the range of precipitation that would cause these floods is 1.6 inches $(40 \mathrm{~mm})$ to 2.1 inches $(53 \mathrm{~mm})$.

- The return period for a storm of 2.1 inches $(53 \mathrm{~mm})$ in this region is approximately 10 years, or less.

Perhaps the most important result was that a storm with a frequency of about 10 years produced a 500-year frequency flow. This shows that the burned portion of the basin had a significant impact on the resulting flows. The primary indicator of a potential increase in runoff due to the fire that was examined by the BAER team was hydrophobicity (chemical change of the soil).

It is true that the selection of modeling parameters, including lag time, $\mathrm{CN}$, storm distribution, and frequency analysis methods, certainly involved a high degree of uncertainty. However, best practices and commonly used methods were employed and justified based on previous studies, and fall within reasonable limits. Owing to the lack of available information, it is possible that different combinations of $\mathrm{CN}$, roughness values, rainfall distribution, and other parameters could yield a similar result. However it is evident that the resulting runoff had a much higher magnitude flood event as compared to what could have come from the estimated rainfall frequency event.

An important result of the Mud Canyon study is that the reduction of ground cover did play a significant role in the increased runoff, especially because the hillsides of the burned watershed are relatively steep (approximately 20\%). Without bushes, grass, etc., to 'hold' the water on the soil, as would have been the case in unburned conditions, water did not infiltrate, even though the soils were not hydrophobic. The problem was exacerbated by several days of rain that left the soils near saturation prior to the larger events that caused flooding.

The literature review in $[10,15,16,18]$ clearly show that increased flows occur in a burned watershed for three to five years following a fire, but they decrease each year. A final result of this study is that a unique approach could be used to solve a problem with various interrelated unknowns. By using WMS, NSS, and HEC-1, this approach could quickly run various iterations to find possible solutions. These solutions and measured values were then used to show how much the flood flow in Mud Canyon Basin had been altered by the fire.

\section{REFERENCES}

[1] Department of the Interior, Southern States Burned Area Emergency Rehabilitation (BAER) Team, Chino Well Fire Burned Area Emergency Rehabilitation Plan, United States Department of the Interior, Bureau of Indian Affairs, Mescalero Agency, 1996.

[2] Waltemeyer, S.D., Analysis of the magnitude and frequency of peak discharge and maximum observed peak discharge in New Mexico, U.S. Geological Survey with the New Mexico Department of Transportation, Scientific Investigations Report 2008-5119, pp. 1-105, 2008.

[3] Miller, J.F., Frederick, R.H. \& Tracey, R.J., Precipitation-frequency atlas of western United States, NOAA Atlas 2, IV-New Mexico, 1973.

[4] CEWRC-HEC, HEC-1 Flood Hydrograph Package User's Manual, Hydrologic Engineering Center, CPD-1A, 1990.

[5] Soil Conservation Service, SCS National Engineering Handbook, Sec. 4, Hydrology, USDA, 1972.

[6] Nelson, E.J., Jones, N.L. \& Miller, A.W., An algorithm for precise drainage basin delineation, Journal of Hydraulic Engineering, 120(3), pp. 298-312, 1994. doi:http://dx.doi. org/10.1061/(ASCE)0733-9429(1994)120:3(298) 
[7] Peucher, T.K. \& Douglas, D.M., Detection of surface-specific points by local parallel processing of discrete terrain elevation data, Computer Graphics and Image Processing, Vol. 4, pp. 375-387, 1975. doi:http://dx.doi.org/10.1016/0146-664X(75)90005-2

[8] Martz, L.W. \& Garbrecht, J., Numerical definition of drainage network and subcatchment areas from digital elevation models, Computers and Geosciences, 18(6), pp. 747-761, 1992. doi:http://dx.doi.org/10.1016/0098-3004(92)90007-E

[9] Department of Commerce, Climatological Data, New Mexico, National Oceanic and Atmospheric Administration, 1996.

[10] Leopold, L.B., Characteristics of heavy rainfall in New Mexico and Arizona, Proceedings, ASCE, pp. 837-892, 1943.

[11] Riverside County Flood Control and Water Conservation District, The application of synthetic unit hydrographs to drainage basins in the Riverside County District, Riverside County, CA, 1963.

[12] Zwolinski, M.J., Effects of fire on water infiltration rates in a Ponderosa Pine stand, Hydrology and Water Resources in Arizona and the Southwest, 1, pp. 107-112, 1971.

[13] Maidment, D., Operational Infiltration Models, Handbook of Hydrology, McGrawHill, New York, p. 5.28, 1993.

[14] Wanielista, M., Kersten, R. \& Eaglin, R., Hydrology: Water Quantity and Quality Control, John Wiley \& Sons, New York, pp. 158, 1997.

[15] Campbell, R.E., Baker Jr., M.B., Folliot, P.F., Larson, F.R. \& Avery, C.C., Wildfire effects on a Ponderosa Pine ecosystem: an Arizona case study, USDA Forest Service Research Paper, RM-191, pp. 1-12, 1977.

[16] Brown, J.A.H., Hydrologic effects of a bushfire in a catchment in south-eastern New South Wales, Journal of Hydrology, 15(1), pp.77-96, 1972. doi:http://dx.doi. org/10.1016/0022-1694(72)90077-7

[17] Lavabre, J., Torres, D.S. \& Cernesson, F., Changes in the hydrological response of a small Mediterranean basin a year after a wildfire, Journal of Hydrology, 142, pp. 273-299, 1993. doi:http://dx.doi.org/10.1016/0022-1694(93)90014-Z

[18] Chow, V.T., Hydrology of Forest Lands and Rangelands, Handbook of Applied Hydrology, McGraw-Hill, New York, pp. 22.31-22.38, 1964. 